\title{
The Pragmatics of Political Claims and Social Responses amidst Covid- 19 and EndSARS Saga in Nigeria
}

\author{
Chioma Deborah ONWUBIKO \\ Directorate of General Studies, Federal University of Technology Owerri, Imo State, Nigeria \\ chiomaonwubikod@gmail.com \\ Favour Ogemdi EGWIM \\ Directorate of General Studies, Federal University of Technology Owerri, Imo State, Nigeria \\ godoffavour@gmail.com
}

DOI: http://doi.org/ 10.36892/ijlls.v3i4.739

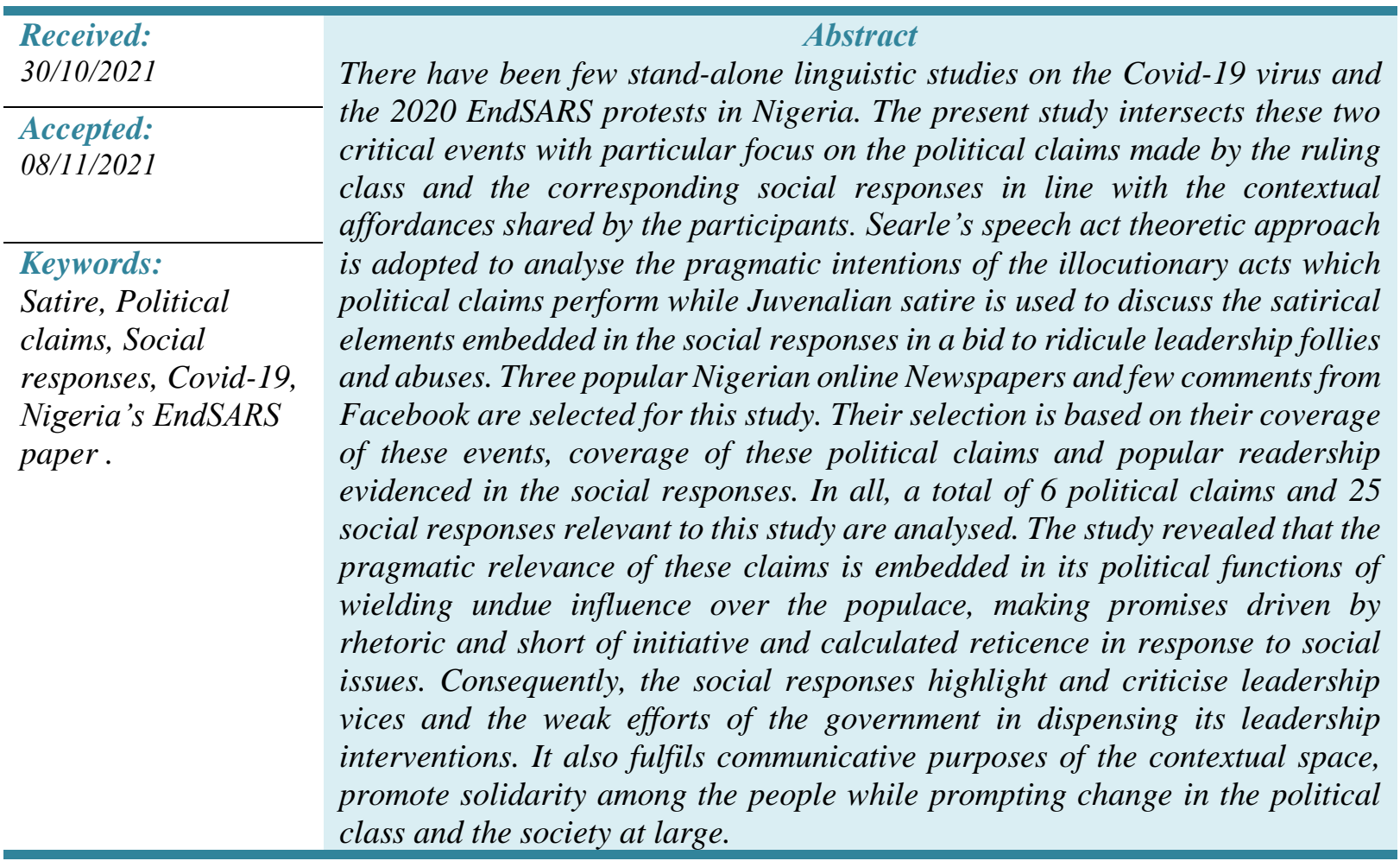

\section{INTRODUCTION}

The outbreak of Covid-19 pandemic at the beginning of 2020 threw a curveball at people's expectations; worsened the already fragile socio-economic conditions in Nigeria and shifted everyone's attention to public health crisis at a huge economic cost. At a point when it seemed that Nigeria has successfully grappled with the pandemic, the impact of the reckless ways in which the supposed containment of the virus was done stared Nigerians in the face. Also the rising unemployment and inflation, inequitable distribution of the palliative, increasing insecurity, the incessant cases of police brutality and extra judicial killings all culminating to the civil unrest that birthed the EndSARS protest, which the present paper addresses.

Moreover, Nigerian government designed and partially implemented numerous policies and projects in a bid to contain the virus and ameliorate the grave consequences of poverty and developmental disorder arising from its effects. However, the newspaper coverage of the 
political claims of how these policies were implemented, palliatives were disbursed and the government's ineptitude towards extra judicial killings in the country, especially that of the EndSARS protesters resulted in the satirical social responses ridiculing the corrupt and nepotistic manner in which the government tackled the scourge as such, yielded no significant result; benefitting only the political elites, leaving the poor masses at their low ebb.

It is on this premise that the present study investigates the communicative intentions of language use by both the ruling class (political claims) and the masses (social responses) in making their stances known. As noted by El-Sayed (2021), language is a performative tool that can be used to accomplish acts that are capable of achieving tangible effects in the real world. Political claims with regard to this study are opinions of government, its representatives or other prominent national figures while social responses are the reactions of the public towards these political claims.

\subsection{From Covid-19 to \#EndSARS Protests in Nigeria}

The petty way with which the Federal Government (FG) handled the outbreak of Covid19 in Nigeria revealed its corrupt and nepotistic dispositions towards national issues. For instance, little planning went into active surveillance, early detection, isolation and case management, contact tracing and preparation of palliative measures for the citizens in the event of a nationwide lockdown which followed afterwards. These leadership lapses and more made the youths to storm the streets in protest as the government seem not to be losing sleep over the increasing security issues and the bestialities of the security operatives even in the midst of the pandemic.

EndSARS is a kind of social movement evidenced by peaceful protests especially by the youth and activists against police brutality and extortion in Nigeria. The protests started from the social media using the hash tag "EndSARS" (Ujene \& Orji-Egwu, 2018). The slogan calls for the proscription of the Special Anti-Robbery Squad (SARS) which was a branch of the Nigeria Police Force under the State Criminal Investigation and Intelligence Department (SCIID). It was established in late 1992 as a masked police unit to perform undercover operations (detain, investigate, and prosecute people) against violent crimes like armed robbery, kidnapping, car snatching and the bearing and use of illegal firearms (Alamba, 2020). However, in recent times SARS became primarily known for several human rights violations and had been accused of illegal arrests and detentions, extortion and torture, kidnappings and enforced disappearances, extrajudicial killings, sexual harassment of women and brutalising of young male Nigerians especially those with alternative hairstyles or dress sense (Tayo, 2020; Uwazuruike, 2020).

News headlines of Thursday 8 October, 2020 reported an unprovoked shooting of a boy in the street of Delta State by SARS officers and were shared on social media (BBC News, 2020) thereafter, nationwide protests on \#EndSARS started after weeks of outrage and anger with trending videos and pictures showing police brutality, harassment, human right abuses and extortion in Nigeria (Alamba, 2020). The protests were led predominantly by young Nigerians in all the six geo-political regions alongside many activists and celebrities calling for reforms and accountability in police operations. Solidarity protests and demonstrations by Nigerians in diaspora and sympathizers occurred in many major cities of the world like the UK, US, Canada and Germany. Moreover, Nigerian security operatives were reported to have disrupted the peaceful protests in some cities; throwing teargas, using water cannons and shooting at unarmed peaceful protesters especially in Abuja and at Lekki Toll Gate Lagos where they converged (BBC News). This led to the death of disputed number of persons; intensifying their call for reforms and accountability in police operations (Aljazeera.com). 
The government having denied responsibility to these stunning indictments through the newspaper headlines; the populace took to the reader's page of the selected newspapers and Facebook to expose this political hypocrisy and incidents such as the foregoing in a bid to birth change and social reform. It is on this basis that the present study investigates the pragmatic effects of political claims made by government and its agencies as regards the happenings in the country and the satirical elements embedded in the corresponding social responses by the public. In the light of this, the study examines how the illocutionary acts embedded in the political claims portray the intentions of the speakers and also how the satirical effects of the social responses are meant to restructure and save the nation from disintegration.

\section{EXISTING LITERATURE AND STATEMENT OF THE PROBLEM}

Linguistic studies on Covid-19 pandemic and EndSARS with bias for Media discourse have largely focused on other areas but the reportage of political claims and social responses on the Pandemic and EndSARS saga. Such studies have only centred on language use (ObiAni, Anikwenze \& Isiani, 2020; Piller, Zhang \& Li, 2020), lexis (Katermina \& Yachenko, 2020), Multimodality approach (Nugraha, Nugi \& Jamaludin, 2020), neologism (Asif, Zhiyong, Iram \& Nisar, 2020) pragmatic acts (Ogungbe, 2020) and few others. The most related study to the present is Ogungbe (2020) who examines discourses on Coronavirus Motivated Humour in Nigeria on Facebook and Whatsapp. While both studies dwell on online forum as data sources, the present study emphasises readers' comments (social responses) to news items especially political claims on e-Punch, Vanguard and Premium Times with few comments from Facebook.

Ogungbe (2020) concentrates on Facebook and Whatsapp, where participants raise and react to issues. Again, while the present study focuses on participants' responses to political claims on Covid-19 pandemic and EndSARS protests, Ogungbe's work centres on Coronavirus-Motivated Humour that reflect the social, economic and health challenges in Nigeria. Yet, both studies aim to reveal the pragmatic relevance of the public perception of government's sense of responsibility as regards citizens' health, security, socio-economic experiences, the sense of citizen's freedom (of speech) validated by ridiculing the ills in the present administration and warning of the imminent danger in neglecting the call to restructure the country. It also provides clearer insights into the satirical constructions that reinforce status difference as well as strengthens the connectedness among the people.

Oleribe, et al (2020), studied public perception of the response of government and its institutions to Covid-19 pandemic in Nigeria through an on-line cross-sectional survey. They noted that the public perception of governmental and its institutional response to the pandemic is very poor. Also other interventions against the pandemic are rated as poor except for the public health communication and prevention messages. The study recommended that a publicprivate partnership should be adopted in the implementation of Covid-19 outbreak policy to streamline perceived and actual inefficiencies. However, the study failed to highlight on the significance of government's feeble effort towards the pandemic on national unity and security, a lapse that the present study addresses.

Soladoye and Ojo (2020), studied the impact of social media on police brutality awareness in Nigeria and noted that social media is the factor that helped to notify the general public of police bestialities and pushed the government into acting fast on the matter. It is also the factor that publicised the awareness and forced the police to take responsibility of their actions. They argue that traditional or mainstream media could not have been that effective. It is true that social media seem like the easiest and fastest means of transmitting information in recent times, but mainstream media like the Channels Television, most local and national newspapers report these issues too. Moreover, the reader's comment section of popular national online newspapers engage in extensive discussions and profound reactions to national issues 
as it affects the populace because participants often conceal their identities perhaps to avoid physical molestations as evident in the data employed for the present study.

Regarding the role of digital technology in the EndSars protest in Nigeria during Covid19 pandemic, Ekoh and George (2021) observe that digital technology make it possible for information to spread easily to the public and most times, with digital video evidence. Thus, protests methods are changing in line with technological advancements hence, government at all levels need to get settled with this fact and not go banning or suspending the use of the social media. Apart from the easy flow of information, this study does not clearly specify the impact of digital technology on government's activities and the people's reactions during the Covid-19 and EndSARs saga towards national interest.

This study, therefore, examines the pragmatics of political claims, the communicative intentions of the social responses, the satirical strategies and its attendant effects as deployed by participants to argue out their stance on political claims made by the ruling class amidst Covid-19 and EndSARS saga in Nigeria.

\subsection{Theoretical and Analytical Tools}

\subsubsection{Searle's Speech Act Theory}

Austin's (1962) Speech Act Theory, which he formulated in his epochal book, How to do things with words holds that utterances are examined from the perspective of their functions rather than their forms as the attitude of the speaker towards his/her proposition is crucial in determining its meaning. Khammari (2021) in describing speech acts opines that discourse participants produce utterances that perform actions in a given context and that is what linguists investigate in order to determine their impact on the society. In developing the theory, Austin described three kinds of acts namely: the locutionary act, illocutionary act and perlocutionary act. A locutionary act is the exact utterance made by a speaker with certain reference while illocutionary act is the function (intention) of the utterance (locution) shared by the speaker and the hearer. For instance, in saying "I will get you a cane", the speaker is probably, promising, warning or threatening the listener depending on the context and the intention of the speaker (Odebunmi, 2003). Perlocutionary act is the effect of the utterance (locution) on the hearer. Searle's taxonomy for classifying the pragmatic meaning of utterance is used in this study because it covers a wider variety of intentions of utterances made by both the ruling class and the general public. Searle (1969) has set up the following classification of Illocutionary Speech Acts:

1. Representatives: are utterances that describe situations through information, assertion, statement, claims, descriptions, conclusions etc.

2. Directives: express what the speaker wants others to do through ordering, instructing, begging, commanding, requesting, suggesting etc.

3. Commissives: express the speaker's commitment to future action; vowing, warning, promising, assuring etc.

4. Expressives: express the speaker's feelings. It involves statements of pleasure, pain, likes, dislikes, joy and sorrow etc. examples are thinking, apologizing, congratulating, condoling etc.

5. Declaratives: are utterances that change the world, this can be appropriately done when the speaker occupies the position to make such declaration. Eg a declaration such as "he is dead" made by a Medical Doctor in a hospital. Other speech acts include resign, adjourn, appoint, nominate, approve, confirm, name, renounce, bless, call, deny etc.

These illocutionary acts are therefore employed to identify the functions of the political claims in the data as well as the corresponding illocutionary forces of both the political claims and the social responses. 


\subsubsection{Juvenalian model of satire}

Satire in some cases has been regarded as a conversational tool that provides the keenest insights into a group's collective consciousness; reveal its deepest values and tastes, and the society's structures of power (Deloria, 1969, p. 146). Although satire is usually meant to be humorous, its greater purpose is often human expression via constructive social criticism Hooley (2007). Knight (2004, p. 96) believes that satire serves to provide psychological release from and/or resistance to dictatorship which is the cause of satire, the object of satire and the ideology of the satirist. Satire is then a discourse that does something, whose theme must be the maintenance of standards, the reaffirmation of values, and the necessity of reform (Zekavat, 2014; Torres, 2020; Bello \& Zainab, 2020).

Juvenalian satire, named for the writings of the Roman satirist Juvenal, is said to be more contemptuous and uncompromising than the Horatian. Juvenal utilized the satirical tools of exaggeration and parody to make his targets appear monstrous and incompetent (Elliot, 2004). Juvenal's pattern of satire abrasively, ridicules and mocks societal structures, power, and civilization by exaggerating the words or position of its target in order to jeopardize their reputation and/or power. It also attacks public officials and governmental organizations, regarding their opinions as not just wrong, but evil. Juvenalian satire addresses perceived social evil through scorn, outrage, and savage ridicule. This form is often pessimistic, characterized by the use of irony, sarcasm, moral indignation, harsh attacks, censure, condescension and personal invective, with less emphasis on humour. Strongly polarized political satire is often classified as Juvenalian (Jonson \& Miola, 2000). A Juvenal satirist's goal is generally to provoke some sort of political or societal change because he sees his target or object as evil or harmful. It is against this backdrop that Juvenalian model of satire is applied in this study in order to tease out the satirical components of the social responses, their effects on Nigerian leaders and their essence as regards socio-political reform. Some strategies of Juvenalian satire identified in the data are discussed below:

i. Savage ridicule: (Violent/harsh) Derisive or humiliating comment about a person for the purpose of making mockery of him.

ii. Irony: Verbal irony is a statement in which the meaning that a speaker implies differs sharply from the meaning that is ostensibly expressed.

iii. Scorn: open disrespect for a person or thing accompanied by intense feeling of dislike and brings about rejection with contempt.

iv. Outrage/moral indignation: a feeling of righteous anger, disgust the act of scandalising.

v. Pessimism: a general disposition to look on the dark side and to expect the worst in all things; the feeling that things will turn out badly.

vi. Sarcasm: witty language used to convey insults or scorn. E.g. (a) Irony is wasted on the stupid. (b) Satire is a sort of glass, wherein beholders do generally discover everybody's face but their own.

vii. Censure: harsh attacks, criticisms or disapproval.

viii. Condescension: the act of patronising, debasing someone morally; an undignified, unworthy or dishonourable comment.

ix. Personal invective: the harsh denunciation of some person or thing in abusive speech or writing, usually by a succession of insulting. Abusive or venomous languages used to express blame or bitter deep-seated ill will.

x. Parody: Conscious imitation of a serious issue for a satiric purpose; exaggerated/ analytic mimicry by means of subversion (destroying someone's honesty or loyalty, undermining moral integrity or opposing civil authority) 
xi. Metaphor: Imaginative description, representation or comparison of something else with the qualities of another.

\subsubsection{Research Questions}

This study aims to examine the pragmatics of political claims and the communicative intentions of its attendant social responses as deployed by participants to argue out their stance amidst Covid-19 and EndSARS saga in Nigeria. In specific terms, the objectives of this study is to answer the questions:

1. What are the illocutionary acts and communicative intentions embedded in the political claims?

2. What are the satirical effects of the social responses?

\subsubsection{Significance of the Study}

This study provides government and the ruling class the awareness that the masses are not unmindful of their political hypocrisy and cruelty as such, it will call their attention to do the right thing as they had promised during their campaign speeches. Also, the study will further promote solidarity among the people to stand for justice and uphold values in the society.

In addition, the study will encourage researchers to get more interested in studying the stances of the masses towards the activities of government in order to instigate reform and promote national unity.

\section{METHODOLOGY}

\subsubsection{Research Design}

The study is a qualitative analysis of the political claims by Nigeria's political leaders and social responses by the masses amidst Covid-19 and EndSARS saga in Nigeria. The political claims are subjected to Searle's taxonomy of illocutionary Acts while the social responses are analysed with Juvenalian model of satire.

\subsubsection{Sample of the Study}

The data for this study are 6 news headlines on the political claims of Nigerian leaders and 25 social responses (readers' comments and reactions) on the happenings that formed the major news in the country which also generated heated reactions and counter reactions on the media among Nigerians in 2020 with regard to the Covid 19 pandemic and the EndSARS saga. The News headlines include: a) Bodies of Covid-19 victims can't be claimed for burial- Lai Mohammed, b) We used N1.32 billion, not N1.5bn to take care of ourselves as COVID-19 palliativeNDDC Chief, c) School Feeding Programme Gulps over N500M during lockdown, says Minister, d) No one was killed in the shootings of \#ENDSARS protesters in Lekki on Tuesday night, e) Governor Babajide Sanwo-Olu has stated , Lekki shootings: "no soldiers were at the scene"- Brutai and f) "I won't allow repeat of EndSARS protests"- Buhari. These six claims and their corresponding social responses have been purposively selected among many other ensuing claims and responses that have sparked off serious controversies on the internet among Nigerians because of their effects on the populace.

\subsubsection{Sampling Technique}

The political claims and linguistic social responses that constitute the data are purposively selected from three popular newspapers and one information site - the online platform of the Vanguard, Punch, Premium Times newspapers and few comments from Facebook. The three are popular newspaper outlets in the country that enjoy unprecedented readership and patronage from a lot of Nigerians, hence it is believed any information got on 
their platform is authentic; their comment section and Facebook gives many Nigerian youths the opportunity to react to and comment on the socio-political happenings in the country.

\subsubsection{Data Gathering Procedure}

The researcher gathered the needed data for this study from the online platform of these three Nigerian newspapers and the Facebook. The researcher selected the headlines and responses that are relevant to the study from the pages of the newspapers and the readers' comment section of the same newspapers respectively. The comments selected from the Facebook are responses based on the headlines selected from the newspapers as some Facebook users post these headline on the pages to attract comments and likes.

\section{DATA PRESENTATION AND ANALYSIS}

This section presents the political claims, which are assertions made by the government, its agency and/or individuals that are part of the ruling political class during the Covid-19 and EndSARS saga in Nigeria, as extracted from the newspaper headlines. The embedded speech acts and the communicative functions of these political claims are analysed. Also the social responses (the reactions of the populace as a result of these political claims) and their pragmatic and satirical effects are presented below:

\section{Bodies of covid-19 victims can't be claimed for burial- Lai Mohammed (Punch,4/4/2020)}

The Nigerian Information Minister, Lai Mohammed during Covid-19 outbreak in Nigeria stated that the virus is so deadly as a result, he informs Nigerians that its victims' dead bodies cannot be claimed for burial by family members rather they will be taken care of by the Ministry of Health as a way of containing the virus. The illocutionary force of this claim is to pressure (sway) Nigerians into seeing and believing the fatal nature of the virus; thereby comply with the guidelines laid down by the Nigerian Centre for Disease Control (NCDC). However, this political claim is swooped on by scornful social responses and comments by Nigerians as a result of the presidency's shilly-shally nature in handling issues.

COM 1: HYPOCRISY 2.0: But Garba Shehu has announced that FG just claimed Abba Kyari's corpse.

COM 2: Baba we don't need the corpses. As no be poor man dey die. The disease is meant strictly for the rich.

COM 3: Double standards! Confused set of people!! God will punish them!!!

COM 4: Lai Mohammed you are next. All of you destroying Nigeria will face destruction

COM 1 patronizes the Minister and perhaps the Buhari led administration as one that is void of any moral integrity hence, he summarises the Minister's assertion with condescension - "hypocrisy 2.0". This savage ridicule is justified by the speaker in a vivid explanation; "FG just claimed Abba Kyari's corpse" contrary to the Minister's claim. Abba Kyari the late Chief of Staff was said to have died of Covid-19, instead of disposing the corpse privately, he was given a grand burial, thus advancing Orwell's dictum "all animals are equal but some are more equal than others". The author exposes government's failure and satirises hypocrisy as a vice which the government needs to address. The illocutionary force is for readers to resist prejudice and for government to jettison nepotism. In COM 2, the participant started by according the Minister some mock respect "Baba"; sounding as if he is in agreement with him but sarcastically clears the air by explaining the reason why "we don't need the corpse"; it's not that of the poor. Most Nigerians especially, the poor believes that the virus could be prevented or taken care of by the intake of some local herbs, spices and stimulants 
which are regular recipe for most poor Nigerians. This participant represents the poor Nigerians, who do not have anyone to speak for them, those who rarely have access to good health facilities, those whose socio-economic status has remained on the low ebb despite their hard work and those who are disheartened by the continuous grand corruption, deep nepotism and cronyism of the present administration. They have become conversant with how Nigerian leaders vacillate from dishonesty to dereliction of duty hence, the sarcastic invective: "the disease is meant strictly for the rich". The rich here represents the greedy corrupt leaders, the illocutionary force of the satire is for the leaders to turn a new leave.

COM 3 employs the censure - "Double standards! Confused set of people!!" to express how untrustworthy Nigerian leaders are and their uncompromising hypocrisy at providing governance. As a result, they often resort to pouring insults on Nigerians, who frown at their feeble and devious initiative. The participant's moral indignation is expressed in his last comment "God will punish them!!!" which is more of a personal invective directed at the leaders at large. The use of the personal pronoun "them" is an indication that it is not just the Information Minister that is involved in this sham but the present administration. Hence, he calls on God to take vengeance on them. The intention of the participant is for the leaders to amend their ways knowing that the Judge of all is watching. COM 4 is a kind of deep-seated ill will towards the Minister and every other person involved in the chaos in the country at the moment. The implicature in the personal invective "...you are next..." is that the speaker wishes the Minister dies like the late Chief of Staff. Again, it implies that the late Chief of Staff was also instrumental to the anarchy stirring the country presently hence, the bitter deep-seated ill will is targeted at all those involved in this laissez faire leadership. The communicative intention is for the leaders to reform the system as their vices have been exposed.

\section{We used N1.32 billion, not N1.5bn to take care of ourselves as COVID-19 palliative- NDDC Chief. (Premium Times, 20/07/2020)}

The NDDC chief, Mr. Pondei deploys the illocutionary act of asserting to inform Nigerians that NDDC staff also felt the effects of covid-19 hence needed the palliative to cushion it. The illocutionary force of the utterance is to make Nigerians understand the fact that it is not only the poor masses that need palliative but also the elite. Moreover, the disclaimer is to make Nigerians feel that he is quite considerate in that he used N1.32 billion (lesser amount) as against N1.5bn which was earlier announced.

COM 5: What is the difference? Confirmed criminal, this is like saying you only stole a Luxury SUV, but did not take the spare Tyre of the same SUV.

COM 6: The silly man fainted! Acting Managing Director of the Niger Delta Development Commission (NNDC), Prof Kemebradikumo Pondei is a good student/ product of the DINO MELAYE School of Drama. The fainting stopped once his traducers asked him to leave. He did not even require a stretcher, yet as unconscious as he appeared or feigned to appear, he could hit back at the hands trying to force his dirty mouth open. I wish they could revive him the native way with ... He must have been so used to fainting. Dino Melaye, your student acted his part well, no be small. Chai!

COM 7: If you are searching for another name for the whiteman's devil; don't just go far; just look towards the direction of those who had governed Liegeria/Nigeria since 1966 till the present ones. There you will find your answer. May Shango hammer you all.L'ashe Edumare. There was never a country; and there will never be a country unless the deceitful contraption is unbundled. Edumare Burst Them... Olodumare Boost Us... 
COM 8: In all honesty I am very disappointed with Buhari, I expected a lot from him based on his stands in 1983. He has surrounded himself with vultures and his war against corruption is anything but sham. Magu was held in custody for over 10 days yet, we have the Minister of Niger Delta who appears to be an unrepentant crook going about his duties as if nothing has happened while being the mastermind of the rot of what is being uncovered at the NDDC.

COM 5 questions the reason for the disclaimer put up by Mr. Pondei, the outrage in author's tone suggests that Pondei has just demonstrated the level of recklessness that pervades the present administration in terms of spending public funds entrusted into their hands with absolute impunity. The participant is overwhelmed by the fact that in the midst of the hunger due to the pandemic and the resulting lockdown which affected the economy; non-payment salaries of some public servants and depriving the hungry masses of the Covid-19 palliative donated by different organisations; a public office holder could brazenly inform the general public that it was a whooping N1.32 billion contrary to the earlier information of N1.5billion that was used as Covid-19 palliative just for the Niger Delta Development Commission (NNDC) alone. As if he could no longer contain his indignation because of this shameless act, the participant condescendingly labels the NDDC chief; "confirmed criminal" and followed it up by analysing the degree of the criminality which is very scandalous for Pondei's personality. One can infer that the participant's choice of words is occasioned by the audacious and unapologetic statement of the NDDC chief; void of any form of compunction. His communicative intention is to let the readers see the fraudulent aspect of Mr. Pondei, the leadership lax on the part of the National assembly and to pressure them to be more responsible.

COM 6 ridicules the action of the NDDC chief, who feigned unconscious when he was being interrogated by the National Assembly as regards his financial recklessness in the commission. The implicature is that he wanted to avoid further interrogation hence, the participant scornfully patronises him by describing him as "silly", his mouth as "dirty" and sarcastically brands him "a good student/product of the DINO MELAYE School of Drama" thus; taking the reader's attention back to Senator Dino Melaye's episode. The participant presupposes that the easiest way Nigerian leaders avoid the law when charged with serious offences is to feign unconscious thus, "the fainting stopped once his traducers asked him to leave..." He wishes that such ridiculous behaviour is greeted with the same derisive response "I wish they could revive him the native way with ..." i.e. he presupposes that pouring cold water on him could have been commensurate. The participant concludes that Pondei must have rehearsed his script so well that he would not even wait for any form of resuscitation or help but left the scene on his own as soon as he was asked to leave. His intention is to expose Pondei's ploy and dissuade the readers from empathizing with him (Pondei).

The participant in COM 7 insinuates that the Whiteman has a devil which he left in the Blackman's country after independence and that is why since then evil (lies, fraud, and deceit) has been resident in "Liegeria". Nigeria is distorted here with the intention of mocking the prevalent corrupt practices of the leaders since independence and highlighting how lie has become synonymous with Nigeria hence; "Liegeria". The speaker presupposes that the law is not the same for everybody, when you are benefitting from the corruption you tend to cover it up; as seen in the actions of the National Assembly members. He harshly denounces Nigerian leaders with the use of some personal invective (invoking some powerful Yoruba deities Shango and Edumare) expressed in colloquialism: "may Shango hammer you all. L'ashe Edumare. Edumare Burst Them..." and is pessimistic about the workability of the "deceitful contraption" called Nigeria hence, "there was never a country; and there will never be a country..." the implicature of the above comment is to convince the readers of the fact that Nigeria was never meant to be and therefore, can never be peaceful. The illocutionary force here is for readers to keep pressing for the division of the country as it was never meant to be. 
And on the side of the government; for them to sit up knowing that the public is no longer at peace with the system.

COM 8 censures the president, Buhari, and blames him for appointing such a fellow as part of his cabinet hence, "I am very disappointed with Buhari... He has surrounded himself with vultures and his war against corruption is anything but sham". The participant metaphorically refers to the political class as devourers who has nothing to add to the existence/wellbeing of the society. Contrary to the case of the EFCC chief, Magu who was detained for some days and some of the stolen money recovered, Pondei "an unrepentant crook" is left to go about his normal business with nothing recovered from him hence, the metaphorical reference "vultures". This implies that Nigerian leaders are devourers; animalistic, harmful and dangerous in nature, there is also clear evidence that same law has different application for different people in Nigeria depending on personal interest. The intention of this participant is to let the public know that Nigerian leaders are only interested in plundering the country and the illocutionary force is for the readers to treat them with disgust perhaps it might push them to change.

\section{School Feeding Programme Gulps over N500M during lockdown, says Minister.}

(Vanguard 03/08/2020)

In the above claim, the minister of Humanitarian Affairs, Disaster Management and Social Development (MHADMSD), Sadiya Farouq via the act of informing has not only claimed that pupils have been going to school during the lockdown but also that they were being fed as well. The illocutionary force of the above statement is to let the readers know that government has been spending a whooping sum to take care of school children despite the lockdown and have them also anticipate more expenditure when school resumes.

COM 9 FB: Nigeria's disaster minister don come again!

COM 10 FB: I can tell you authoritatively that someone will attempt to faint before the house of reps members next week. How can you spend 500m feeding school children during lockdown?

COM 11 V: Another looting scandal loading

COM 12 V: Stupid fake policy...

The scornful distortion of the Minister's designation in COM 9 is a conscious parody and a ridiculous epithet that condemns the brassy acts of corruption, deceit and injustice by the political actors. The speaker laments on the kind of misfortune that has befallen Nigeria on the account of the Minister and reminds the readers of the fraudulent characteristics associated with her. The presupposition drawn from the colloquial expression "...done come again" is that the Minister is in the habit of announcing outrageously bloated figures expended by this administration on undeserving projects while neglecting worthwhile ventures. The illocutionary force of COM 9 is for the readers to see the Minister as a disaster and a misfortune to the masses.

Advancing the ongoing argument, COM 10 infers that the Minister's mendacious pursuits would surely warrant probing by the National Assembly upon which she will behave like her collaborator, Pondei because there would be no justifiable defence for misappropriating public fund. The participant shockingly questions the possibility of spending such a ridiculous amount on school feeding while school children are still at home, he leaves the readers with the illocutionary force of reasoning out the validity of the Minister's claim. The derisive and 
scornful utterances in COM 11 and 12 is quite condescending and suggests that the Minister's claim is mendacious and the participants want the readers to be abreast with the despicable intentions behind the delusion of school feeding. The illocutionary force of the COM 11 and 12 is for the readers to resist this school feeding programme as it has no benefit to the poor masses; perhaps in doing this, the government will have a change of mind for good.

\section{No one was killed in the shootings of \#ENDSARS protesters in Lekki on Tuesday night, Governor Babajide Sanwo-Olu has stated. (Premium Times, 21/10/2020)}

The Lagos state governor, Babajide Sanwo-Olu on Wednesday morning, a day after the Lekki Massacre stated that the unarmed EndSARS protesters were actually shot at but denied the fact that lives were lost as a result of that. By implication, the governor's claim seeks to convince the general public that the situation is under control. The illocutionary force of the above assertion is to get the public debunk the rumour of bloodbath at Lekki Toll Gate.

COM 13 FB: Obviously nobody was killed... Glory to God!!! Everybody had odeshi!!!!

Killer leaders!!!@JideSanwo-Olu this generation and generation yet to come will read of your genocide at Lekki today. Your record is written forever.

COM 14 FB: For the sake of clarity, nobody burnt TVC news house. It was caused by electrical fault. As for the BRT buses, a dragon vomited fire and burnt them. Regarding Sanwo-Olu mother's residence, it was caused by power surge including other buildings set ablaze, which was due to thunder.

Me: No be only government sabi lie!

COM 15 FB: Brutai, Tinubu, Buhari, Sanwo-Olu - Murderers! May the blood of the innocent Youths you killed hurt you and your generation forever. IJN

COM 16 PT: Sanwo-Olu is confused. He takes orders from Tinubu and that is why he is unstable as a typical Yoruba man.

Despite the governor's claim and persuasions, the public refused to be inveigled into believing that shooting at unarmed protesters was a mere harmless exercise hence the sarcastic and ironical response "Obviously nobody was killed... Glory to God!!!" in COM 13 which is followed by personal invective "Your record is written forever". The speaker implicitly informs the readers that certainly lives were lost as it is not possible that all the EndSARS protesters had odeshi-traditional bullet proof. Moreover, one could sense his indignation at the governor as he reminds him that the consequences of his monumental foolhardiness will remain indelible in people's mind. The illocutionary force of this response is to let the readers know that Nigerian politicians are not to be taken by their words. The sarcastic clarification in COM 14 consists of a myriad of irony and implicit mockery employed by the participant in explaining the cause of some of the incidents that took place during the protest. This satiric mimicry is deliberate and tactically exposes the political propaganda that characterise the present administration and has also become the normal in Nigeria. The participant's parody is an attempt to depict the deceit and wickedness of the political class who are in the habit of denying and/or feigning ignorance whenever a dastardly act is done under their watch as can be inferred in the governor's claim above. The implicature here is that the governor was too quick to deny and cover up the carnage that was perpetrated by the military in his state. "No be only government sabi lie" is a colloquial expression deployed by the speaker to imply that he 
concocted the supposed clarification just to get back at the government and the illocutionary force is to make the readers realise that government has lost every sense of decency, honesty and transparency and as such should not be trusted.

COM 15 boldly mentions the names of some political actors whom he blames for the atrocity and labels them Murderers, in so doing he informs the readers of the alleged perpetrators of the Lekki Toll Gate massacre and passes a vindictive comment on them. The readers are left with the illocutionary force of thinking of these men as troublers of the nation. COM 16 makes a condescending comment on the governor by mocking his leadership abilities thus "Sanwo-Olu is confused". The participant further ridicules him by implying that he is not the one in charge of the state rather a former Lagos State governor, Tinubu is and he concludes that this instability in character is not atypical of a Yoruba man. The communicative intention behind uttering (16) is to inform the public of the kind of leaders saddled with the task of protecting them and the attendant illocutionary force is to let the public know that there are powers that control the state from behind the scene hence, they need to be more vigilant and aware that government alone cannot give them adequate protection.

\section{Lekki shootings: "no soldiers were at the scene"- Brutai (Punch 21/10/2020)}

The political claim above by the Chief of Army Staff, Gen. Tukur Buratai denies deploying soldiers to the tollgate despite contrary video and oral evidence by the CCTV footage and eye-witnesses. The implication of the claim is for the military to be exempted from the blame for any form of mishap that happened at the tollgate. The illocutionary force of the claim above is to make the public believe that there was no military man at the tollgate and therefore could not have been aware talk more of perpetrating the alleged massacre.

COM 17: Buradie has a penchant for denying when he has deployed his boys to kill innocent ones. May the blood of the innocent ones that were lost be upon you.

COM 18: I thought as much! I knew it! Everything about this govt is LIES! DECEPTION! These multiple lies and denials by the military are stomach heaving. These unprofessional lies will not help matters but create more problems. We know the truth already so stop lying! God will surely expose every enemy of this Great Nation Nigeria!!!

COM 19: When BUHARI dey lie, Lie Mohammed dey lie, Police dey lie, Sanwo-Olu dey lie, MILITARY gassss to lie... Nobody expected you to accept responsibility for this evil acts. Idiots. The next thing is for Oga Presido to add that he was shocked by the killings!

COM 20: Fuck you Buhari, Brutai, Frog eye (Tinubu) and drug addict (Sanwo Olu) koni cool fun gbo yin... you have all murdered sleep in Lagos... Sanwo Olu your mother's house @ Akerele Surulere will be grounded. Bastards.

COM 21: May what happened in Lekki toll gate happen in the homes of Buhari, Osibanjo, Ahmed Lawan, Gbajamiala, Buratai, Boss Mustapha, Tinubu and the entire APC, may they suffer the losses of their children before the end of 2020. May Amadioha combine forces with Sango, Ogun, Oyo and the pit of hell to wipe off the generations of these evil beasts who ordered the massacre of innocent youths. May all who played any role directly or indirectly partake in the DESTRUCTION and ANGER of God that will follow this dastard actions of Buhari and APC whose only interest is to embezzle public fund, May the blood of the departed souls never stop asking for 
vengeance from Buhari, Buratai, Bola Tinubu and co who did this evil. May Garuba meet his death in suffering and shame, may they all DIE Misreably after burying their own children. It Will NEVER be well for Buhari, NEVER.

The participant in COM 17 distorts the name Buratai for Buradie and passes a vote of censure on Buratai's perceived inclination to lying and murderous tendencies. He lets out an invective with the intention of letting the readers know that Buratai should not be trusted with the truth as he is in the habit of lying and shedding innocent blood. COM 18 is pessimistic with the present administration because of their seeming irresponsibility with lives that supposed to be their priority to cater for. The participant scorns their unethical behaviour, which only worsens the already bad situation and reminds them that it is foolishness to try to cover what is bare already. He finally commits them to God who alone sees in the secret and exposes in the open. Invoking the powers of the Almighty for vengeance portrays the author's religious affinity and gives his utterance a force. The participant's assertion is intended to make the readers believe that this government is ruthless, deceitful and therefore an enemy to the people of Nigeria.

COM 19 is a mockery of the key political actors who have been devious in handling the genocide that happened at the Lekki Toll Gate. He informs them that there was no need lying as Nigerians are well accustomed to their routine craftiness, the condescending and metophoric reference "idiots" connotes their animalistic tendencies. He further parodies Mr. President's usual impulsive manner of responding to similar cases thus, "The next thing is for Oga Presido to add that he was shocked by the killings!" The illocutionary force of the above comment is for the readers to know that the parties involved in this present administration is not dependable and they should never expect more from them. COM 20 deploys a condescending tone to address four major political actors in the present administration and curses them though colloquially "Fuck you... koni cool fun gbo yin..." meaning that they will never have it cool in life. He ridicules them and alleges that they are the masterminds of the tragedy that wrecked Lagosians that fateful day; since they stirred up unrest the implication is that no one will rest including them. The presupposition drawn from the last statement "SanwoOlu your mother's house @ Akerele Surulere will be grounded" is that Sanwo-Olu will be a beneficiary of the unrest as he could not protect the armless protesters under his watch as the Lagos State governor. He ended with a debasing label for the political actors "basters". The communicative intension here is to awaken the consciousness of the readers that an abomination has been committed in the land and the illocutionary force is for the readers to rise and even the score.

COM 21 is a personal invective by the participant to express disgust, blame and bitter deep-seated ill will on the political actors that he mentioned their names. Out of outrage, he invokes some terrible gods of the land as well as God to avenge the death of the innocent protesters that lost their lives defending their father-land. The invocation of these terrible gods and the Almighty God further portrays the religious beliefs of Nigerians and their trust in the efficacious justice of these powers in handling such matters. The illocutionary force is to instigate a passionate rage in the readers against Nigerian leaders.

\section{I won't allow repeat of \#EndSARS protests - Buhari (Vanguard, 18/11/2020)}

President Mohammadu Buhari promises and assures Nigerians that he will do "whatever it takes" to stop the protests from happening again. Two illocutionary forces interpreted from the President's promise are first; to let the masses know that government is aware of the issue at hand and is determined to map out strategies to address the issue, second is to urge Nigerians to have confidence in his administration to curb the menace. 
COM 22: I am worried for the future of Nigeria under President Buhari in the sense that Nigeria has been slick in blood and sorrowing day by day without let. It takes a particularly brutal mind to order the national army to point rifles at citizens and shoot the citizens dead. President Buhari has proved that he possesses such brutal mind. The country's interest can be better served by removing Buhari from office to be replaced by an educated person who can think properly. Nobody in Nigeria can point out for me a complete sentence made by President Buhari without reading a prepared speech which made complete sense in logic and was entirely truthful without lies embedded.

Why should well-educated Nigerians be held hostage by such a dim president?

\section{COM 23: I WILL NOT SUPPORT any PROTEST THAT DOESN'T TARGET MR BUHARI HIMSELF AGAIN!}

COM 24: That's the emir of Nigeria speaking. He owns us; but only a delusion. The only way he can stop EndSARS is by checkmating his fantastically corrupt administration, his ineptitude and nepotism. Otherwise, I would prophesy - things have only just started.

COM 25: The new-born democrat has spoken, what else! These parasitic leaders don't know that what is looming now is the war of the angry, famished, impoverished and helpless and poor against the sadistic rich!

The participant in COM 22 is pessimistic about a future with the present administration as it is characterised by bloodletting. He does not only point out the political and social vices bedevilling the present administration, he makes it clear that it is intolerable hence the call for his removal owing to his clueless reactionary approach to national issues. He advocates for a more learned person to take over the leadership of the country as he ridicules and scorns his poor educational attainment which he attributes as the paramount factor for his inability to address any gathering without relying on an already prepared deceit-infested speech. The communicative function of the rhetorical question is to induce the readers to push for reformation. COM 23 is a flagrant outburst of moral indignation directed at the President; the participant vows and assures the readers of his resolve to henceforth confront and criticise Buhari's taciturn and rhetorical response to portentous national issues. The illocutionary force of this utterance is to incite the readers to campaign for political change and reform.

COM 24 is a savage ridicule of the dictatorial leadership style of Mr. President evidenced by a track record of tactical reticence over matters of impropriety concerning members of his close circle of aides, embellished nepotism which pooh-poohs his anticorruption crusade. The communicative intention of the writer is to get Mr. President to assume his leadership role and perhaps salvage his rapidly crumbling reputation and to make the readers to picture the insincerity of this administration. The participant in COM 25 deploys analytic mimicry and condescension to describe the type of leaders that make up the present administration, he threatens and warns them of the imminent ominous descent into anarchy if the "sadistic rich" do not turn a new leave. The presupposition of this utterance is to inform the poor Nigerians of the ugly fact that the ruling class is getting richer by impoverishing them and they therefore, need to act fast. The illocutionary force is for Nigerian government to restructure the country to avert resurgence of the mayhem that characterised the recent EndSARS protests.

\section{SUMMARY OF FINDINGS}

Table 1: Distribution of Illocutionary Acts performed in the Claims and Satirical Devices in the Responses. 


\begin{tabular}{|c|c|c|}
\hline Claims & $\begin{array}{l}\text { Speech } \\
\text { (Claims) }\end{array}$ & Satirical Devices (Comments) \\
\hline 1 & $\begin{array}{l}\text { Representatives: } \\
\text { State, Inform }\end{array}$ & $\begin{array}{l}\text { 1. Condescension, Ridicule, 2. Sarcasm 3. Outrage, } \\
\text { Censure, Personal Invective 4. Personal Invective }\end{array}$ \\
\hline 2 & $\begin{array}{l}\text { Representatives: } \\
\text { Assert, Inform } \\
\text { Disclaim }\end{array}$ & $\begin{array}{l}\text { 5. Condescension, Outrage, } 6 \text {. Ridicule, scorn, sarcasm } \\
\text { 7. Personal Invective, Mockery, Colloquialism, Pessimism } \\
\text { 8. Censure, Metaphor }\end{array}$ \\
\hline 3 & $\begin{array}{l}\text { Representatives: } \\
\text { Inform, Claim }\end{array}$ & $\begin{array}{l}\text { 9. Savage Ridicule, Parody, Scorn 10. Outrage/Moral } \\
\text { Indignation } \\
\text { 11. Scorn, 12. Condescension }\end{array}$ \\
\hline 4 & $\begin{array}{l}\text { Representative: } \\
\text { Assert, Convince }\end{array}$ & $\begin{array}{l}\text { 13. Irony, Sarcasm 14. Irony, Sarcasm, Mockery, Parody, } \\
\text { 15. Personal Invective, 16. Salvage Ridicule }\end{array}$ \\
\hline 5 & $\begin{array}{l}\text { Declaratives: } \\
\text { Declare, Deny }\end{array}$ & $\begin{array}{l}\text { 17. Censure, Invective 18. Pessimism, Scorn, } \\
\text { 19. Mockery, Condescension, Parody, Metaphor } \\
\text { 20. Condescension, Ridicule } \\
\text { 21. Personal Invective, Outrage }\end{array}$ \\
\hline 6 & $\begin{array}{l}\text { Commissives: } \\
\text { Promise, Assure }\end{array}$ & $\begin{array}{l}\text { 22. Pessimism, ridicule, scorn, censure } \\
\text { 23. Moral Indignation, } \\
\text { 24. Savage ridicule } \\
\text { 25. Analytic Mimicry, Condescension }\end{array}$ \\
\hline
\end{tabular}

\section{CONCLUSION}

This study examined the pragmatic functions of political claims and satirical devices embedded in the social responses in three Nigerian Newspapers and few Facebook comments amidst Covid-19 and EndSARS saga in Nigeria. The data analysed reveal that the political claims consist of the representative acts (informing, stating, asserting and dis/claiming) more than the declarative (declaring and denying) and commissives (assuring and promising). The use of these speech acts is dependent on the pragmatic context of speech and communicative intention of the speaker. From the findings, it is obvious that the despicable activities and claims of the political class manifesting in empty promises void of initiative, calculated reticence in response to social issues and grand corruption have made Nigerians not to give a hoot in ridiculing, mocking, censuring, parodying, condescending, scorning, and expressing indignation towards their obnoxious acts; backing them up with blames and invectives as they have seemingly become pessimistic over time and have adopted these strategies as a form of resistance from domination. Yet at the centre of these satiric reactions of participants are promotion of solidarity among the people, implied reaffirmation of values and a call for reform in all the sectors especially, on the area of corruption, sectionalism, political hypocrisy and cruelty among others.

\section{REFERENCES}

Alamba, S. (2020). Nigeria: Crackdown on Police Brutality Protests. Human Rights Watch, 10 (1), pp. 3

Aljazeera.com. (2020) "We need to live': Young Nigerians on why they are protesting". aljazeera.com. Archived from the original on 14 October 2020. Retrieved 15 October 2020

Asif, M., Zhiyong, Z., Iram, A. \& Nisar, M. (2020). Linguistic Analysis of Neologism Related to Coronavirus. Social Sciences and Humanties Open (Under Review)

Austin J.L. (1965). How to Do Things with Words. Oxford University Press, Oxford.

BBC News. 12 October 2020. "Sars ban: Two dead in Nigeria police brutality protests". Archived from the original on 12 October, 2020. Retrieved 13 October 2020 
BBC News, October 16, 2020. End SARS: How Nigerian's Anti-police Brutality Protests went Global. Archived from the original on 16 October, 2020. Retrieved 17 October 2020

Bello, U. M., \& Zainab, R. A. . (2020). Complexity in the Noun Phrase Structure of the Nigerian EFCC Act. International Journal of Linguistics and Translation Studies, 1(1), 54-63. https://doi.org/10.36892/ijlts.v1i1.12

Deloria, V. (1969). "Indian humour", Custer died for your sins: An Indian Manifesto.

Ekoh, P.C. \& George, E.O. (2021). The role of digital technology in the EndSars protest in Nigeria during Covid-19 pandemic. https://doi.org/10.1007/s41134-021-00161-5

Elliot, R. (2004). Satire $18^{\text {th }}$ ed., Encyclopaedia Britannica Inc.

El-Sayed, W.A. (2021). Language performativity and horror fiction: A cognitive stylistic approach. International Journal of Language and Literary Studies, 3(3), 225-243. DOI: http://doi.org/10.36892/ijlls.v3i3.647

Hooley, D. M. (2007). Roman Satire. Malden: Blackwell.

Jonson, B. \& Miola, R. S. (2000). Every man in his humour: Quarto Version. Manchester University Press.

Khammari, H. (2021). Strategies and mitigation devices in the speech act of disagreement in American English. Studies in Pragmatics and Discourse Analysis, 2(1), 26-39. https://doi.org/10.48185/spda.v2i1.243

Katermina, V. \& Yachenko, E. (2020). Axiology of Covid-19 as a linguistic phenomenon in English mass media discourse. Advances in Journalism and Communication, 08(02), $59-72$

Knight, C. A. (2004). The Literature of Satire. Cambridge and New York: Cambridge University Press.

Nigeria Centre for Disease Control. (2020, August). Covid-19 Nigeria, 2020. Reyrieved from https://covid19.ncdc.gov.ng/Accessed; 12 August 2021

Nugraha, D., Nugi, A. \& Jamaludin, M. (2020). Multimodality in Covid 19 Pandemic Based

on Corpus Linguistics Perspectives. Psychosocial International Journal of Psychosocial

Rehabilitation. Vol 24(1).

Obi-Ani, N.A., Anikwenze, C. \& Isiani, M.C. (2020). Social media and the Covid-19 pandemic: Observations from Nigeria. Cogent Arts \& Humanities, 7:1, 1799483

Odebunmi, A. (2003). Pragmatic features of English Usage in Hospital interactions among Medical Practitioners and Patients in South-Western Nigeria. Unpublished Ph.D Thesis, Department of English, Obafemi Awolowo University Ile-Ife

Oleribe, O., Ezechi, O., Osita-Oleribe, P., Olawepo, O., Musa, A., Omoluabi, A., Fertleman, M., Salako, B. \& Taylor-Robinson, S. (2020). Public perception of Covid-19 management and response in Nigeria: a cross-sectional survey. Retrieved from: http://bmjopen.bmj.com/ on August 23, 2021.

Ogungbe, E. O. (2020). The pragmatics of Coronavirus Motivated Humour on the Social Media. All Nations University Journal of Applied Thought (ANUJAT), 8 (1):1-20. All Nations University Press. Doi:http://doi.org/10.47987/OURO2156

Piller, I., Zhang, J., \& Li, J. (2020). Linguistic diversity in a time of crisis: Language challenges of the Covid 19 Pandemic. Multilingua. 39(5). De Gruyter.

Searle, J.R. (1979). Speech Acts: an essay in the philosophy of language. New York: Cambridge University Press.

Soladoye, A.A. \& Ojo, A.O. (2020). Impact of social media on police brutality awareness in Nigeria. International Journal for Management and Modern Education, 1(1), 14-27.

Tayo, T. (2020). \#EndSARS to \#EndSWAT: Nigeria needs real change/ Africa at LSE blogs.Ise. ac.uk. October $16^{\text {th }}$, 2020. http://blogs.Ise.ac.uk/africaatlse/2020/10/16/ endsars-to- endswat-nigeria-needs-real-change/

Torres, J. (2020). Politeness Strategies vis-à-vis Genders and Exposures to Western Culture: The Case of 'The Voice of the Philippines' Coaches. International Journal of 
Linguistics and Translation Studies, 1(3), 100-117. https://doi.org/10.36892/ijlts.v1i3.1

Ujene, I. G. \& Orji-Egwu, A. O. (2018). "Information Communication Technology as a Tool for Social Control: A Study of Nigeria's \#EndSARS". Journal of Human Capital Development (JHCD), 11 (2): 1-16.

Uwazuruike, A. (2020). \#EndSARS: The Movement against Police brutality in Nigeria. Harvard Human Rights Journal, November 12, 2020.

Vanguard March 1, 2020. How we detected Nigeria's first Coronavirus case -Olumuyiwa, virologist

Zekavat, M. (2014). A Discursive Model of Satire. Jena Electronic Studies in English Language and Literature, 2014 - 001.

\section{AUTHORS'BIO}

Chioma Deborah Onwubiko is a lecturer at the Federal University of Technology Owerri, Imo State, Nigeria. She is a seasoned researcher, teacher and prolific writer. She has presented published papers in conferences and also written quite a number of published works including book chapters in both national and international journals. Her area of research interests includes: pragmatics, discourse analysis and psycho-socio linguistics. She is currently rounding up her PhD dissertation in English Studies at the University of Ibadan, Nigeria.

Favour Ogemdi Egwim is a lecturer and a researcher at the Directorate of General Studies, Federal University of Technology Owerri, Imo State, Nigeria. She is an active, curious and communicative teacher. She has also presented papers at conferences and published articles in reputable journals. Her research interest spans Sociolinguistics, Pragmatics and Communication arts. She is currently doing her PhD in English Studies at the Imo State University, Owerri, Nigeria. 